\title{
Brent Lovelock
}

\section{Single Worthwhile Policy, Seeking Legitimacy and Implementation:}
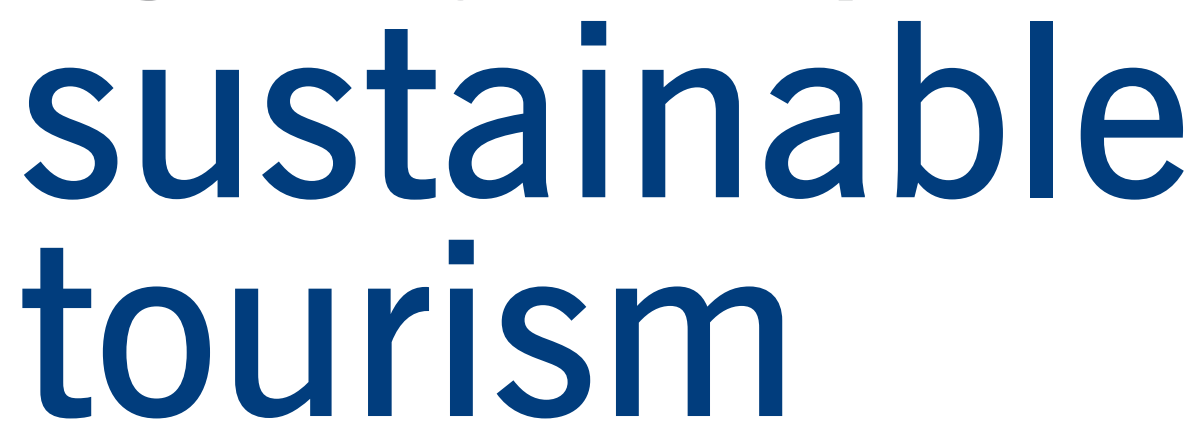

\section{at the regional destination level, New Zealand}

Despite sustainability becoming a key discourse throughout the tourism industry, the practical implementation of sustainable tourism policies has been limited (Hall, 2011).

New Zealand is not immune to criticism in this regard and our ' $100 \%$ Pure' tourism brand has been brought into question. As long ago as 1997 the Parliamentary Commissioner for the Environment reported that the environmental qualities underpinning tourism were at risk and that visitor pressure on iconic attractions could not be sustained. Importantly, the commissioner identified 'systematic problems that hinder the achievement of sustainable tourism', noting that 'the government system for managing tourism and its environmental effects is fragmented' (Parliamentary Commissioner for the

Environment, 1997,p.5).In order to address these matters, a specific recommendation in the report was that the Ministry of Tourism facilitate the development of a strategy for sustainable tourism for New Zealand.

Flash forward to 2011. Fourteen years have passed and international visitor numbers have climbed from 1.5 million in 1997 to 2.5 million. The country now has a dedicated tourism strategy; in fact two such strategies have been produced, the first in 2001, followed by an update in 2007 (Tourism Strategy Group, 2001; Ministry of Tourism, 2007). But have the problems identified in 1997 been addressed? Do we now have a 'sustainable tourism' industry? Connell et al. (2009) in their review of tourism strategies and sustainable tourism in New Zealand describe the Commissioner for the Environment's report as 'somewhat outdated yet still sadly relevant'. Further, a range of other impacts have been documented which offer little indication that tourism is becoming any more sustainable. So what has gone wrong?

The idea of sustainable tourism has been well articulated in both of New Zealand's national tourism strategies. We have, in our national policy documents, a commitment to the concept of managing environmental, social, cultural and economic resources for present and future 
generations. However, governments have become 'extremely canny in reproducing the sustainable development rhetoric without actually effecting fundamental policy shifts' (Dredge and Jenkins, 2007, pp.285-6). At the regional and local levels too we have witnessed over the last decade a virtual explosion in the number of tourism plans and strategies (Connell et al., 2009), most of which espouse a central tenet of sustainable tourism, yet the extent to which such policies have guided sustainable tourism development within their constituencies is unclear.

This article considers this apparent 'implementation gap', and how the norms of sustainable tourism may be translated to the local level. The view is advanced that sustainable tourism implementation is essentially a governance issue, exacerbated by legislative complexities within the policy domain. I argue that there is an overriding crisis of legitimacy for tourism policy, and that this impedes sustainable tourism outcomes. The article begins by discussing literature relevant to the governance and operationalisation of sustainable tourism, before briefly addressing the New Zealand Tourism Strategy and responses to it. It then focuses on two southern destinations, Queenstown and the Catlins, quite different in terms of visitor numbers and pressures but both facing challenges in terms of how tourism policies are translated into workable policies for local planners and tourism industry stakeholders.

\section{Sustainable tourism}

Sustainable tourism is defined by the United Nations World Tourism Organisation as:

Tourism that takes full account of its current and future economic, social and environmental impacts, addressing the needs of visitors, the industry, the environment and host communities. (UNWTO, 2004, pp.11-12)

While the jury is still out on the extent to which, globally, we have achieved sustainable tourism (e.g. Hall, 2011, describes it as a 'policy failure'), there is general agreement that destinations that want to promote sustainable tourism are more likely to be successful when there is effective governance (Bramwell, 2011). While governance may be interpreted in a number of ways, of importance here is what governance scholars refer to as governing systems, which provide means for 'allotting resources and exercising control and coordination' (Rhodes, 1996, p.653).

There are substantial difficulties that can hinder effective governance for sustainable tourism (Bramwell, 2011). Notably, many tourism concerns are cross-sectoral, and consequently span a number of policy domains: e.g. planning, transport, environment and employment. Ruhanen et al. (2011), for example, identify 222 Australian acts which have an impact on tourism. Consequently, policies affecting sustainable tourism are often made in policy domains other than tourism, 'with little attention paid to the implications for tourism' (Bramwell, 2011, p.461). Coordination and cooperation are thus special issues for sustainable tourism, as the relevant actors are found in a variety of sectors (Bramwell and Lane, 2000; Dinica, 2009).

While tourism governance may be influenced by a broad range of actors, it is generally agreed that the state has a critical role to play because of the noted characteristics of the sector. Indeed,

'holistic ambitions of sustainable development and the multidisciplinary nature of tourism entail that only governments and public authorities can coordinate efforts in sustainable tourism policy at both the national and local levels' (Wearing and Neil, 2009, p.44).

\section{Sub-national tourism governance}

Effective local governance is thus a central element of aholisticandbalanced approach to sustainable tourism (UNEP, 2003). However, the view of local government has become less holistic, and it is increasingly common for local governments to support a pro-economic development approach to local tourism policy', focusing just on the marketing and promotion of tourism (Beaumont and Dredge, 2009, p.8). This view is supported by studies of local government tourism policy which reveal a focus on expanding tourism and generating revenue and employment (e.g.
McLennan and Ruhanen, 2008). The operational objectives of regional tourism organisations (RTOs), their organisational skill sets, funding structures and processes have often been geared towards marketing, with little or no attention given to tourism planning or sustainable tourism (Dredge et al., 2011). But despite these and other limitations (instability, disparity of functions, poor resourcing) (Pike, 2004), RTOs are still the major player in tourism policy implementation (Zahra, 2011).

\section{Policy legitimacy}

Here I introduce the concept of policy legitimacy, as arguably a core component of 'good governance' and as a useful framework for considering the challenges of sustainable tourism policy implementation. Policy legitimacy can consist of two components: a normativemoral component (the policy needs to be consistent with the political values and norms within society); and a cognitive component (the policy needs to be seen as feasible) (George, 1980, in Smoke, 1994). Both of these components are essential, especially for long-term policy - e.g. for sustainable tourism. Rothstein (2008) identifies two different sources of legitimacy. Input (or procedural) legitimacy refers to how policy choices are made and by whom. This is linked to procedures for involving stakeholders. Output (or substantive) legitimacy refers to the general acceptance of policy decisions made by the authority, that is the laws, directives, regulations and their implementation. Rothstein argues that legitimacyis more dependent on the output side of the political system, i.e. acceptance by the public and implementing actors, and perceptions of 'implementability'.

It is contended here that within the tourism policy domain in particular, output legitimacy for local tourism strategies is challenged. A number of factors are implicated: legal status of policy and integration with statutory processes; resources, image and power of implementing bodies; and coordination and cooperation of key stakeholders. These factors will be explored in the following discussion of tourism policy, nationally and in the two regional destinations. 


\section{New Zealand governance for tourism}

The policy environment for sustainable tourism in New Zealand is complex (Connell et al., 2009). Effectively there are two quite separate domains: a specific sectoral tourism domain, and a more encompassing resource management domain. Within the former, there is no legislative requirement for the production of tourism strategies in New Zealand, either at the national or local level. The New Zealand Tourism Board Act 1991 created the New Zealand Tourism Board, whose object is 'to ensure that New Zealand is so marketed as a visitor destination as to maximise long-term benefits to New Zealand'. Although the give little recognition to the importance of tourism within their district plans (Local Government New Zealand, 2004).

Importantly, there is no legislative foundation for linking national or local tourism planning with the RMA. Despite the existence of tourism plans or strategies within districts, many remain quite narrow in their focus - adopting a traditional marketing perspective - with a view to promoting tourism in a region rather than creating clear links to the RMA (Connell et al., 2009) and thus to the sustainable development needs of the destination. Notwithstanding these shortcomings, undeniably TLAs, either themselves or through their RTOs,

\section{Poor resourcing, uncertainties over continuity of staffing and support, the strains of volunteerism, personality conflicts, and intra-regional conflict have ultimately hamstrung the organisation that did emerge through the strategy}

functions of the board include developing, implementing and promoting strategies for tourism, arguably these are all implicitly promotional strategies.

The importance of the Resource Management Act 1991 (RMA) as the umbrella legislation for sustainable resource management, and the role of territorial local authorities (TLAs) as having primary responsibility for planning at the local level are widely acknowledged. Tourism, however, is not specifically addressed in the RMA, which adopts an effects-based approach to assessing development proposals rather than an activity-based approach. Connell et al. note that some TLAs may have interpreted this absence as meaning that tourism is not an activity that requires attention in relation to the identification of impacts and delineation of associated policy and management responses' (Connell et al., 2009, p.70). Consequently, many districts and regions have a key role to play in the 'effective translation of principles into policy and action ... to progress the sustainability agenda' (Connell et al., 2009, p.870). This is explicitly recognised within the New Zealand Tourism Strategy 2010, which states that '[1] ocal government has the mandate for tourism planning and destination management' (Tourism Strategy Group, 2001). It envisages 'New Regional Tourism Organisations' which will take an enhanced role in destination marketing and management.

In response to the New Zealand Tourism Strategy 2010, Local Government New Zealand, the umbrella group for TLAs, called for their members to 'engage communities in planning for tourism which is socially, economically, environmentally and culturally sustainable' (Local Government New Zealand, 2003, p.6). Notably, they explicitly acknowledged the need to supplement the statutory planning framework of the Resource Management Act with non-statutory tourism strategies which better address tourism growth and its effects (Local Government New Zealand 2003). Their Tourism and the Resource Management Act: a good practice guide (2004) outlines a number of statutory and non-statutory mechanisms for enhancing local government planning for sustainable tourism, including the RMA, the Local Government Act 2002, long-term council community plans, bylaws, annual plans, asset management plans, waste management plans, land transport programmes and reserve management plans. They espouse a 'Planned and Integrated Response with Multi-Agency Participation e.g. regional tourism strategy linked to infrastructure investment, district and regional plan policy and RMA methods' (p.7).

A problem faced here, though, is that most tourism strategies are still being written from a destination marketing perspective (Local Government New Zealand, 2004). The lack of any grist behind the sustainable tourism rhetoric in regional New Zealand tourism plans is revealed in Connell et al.'s 2009 survey of tourism planning within TLAs. Few plans noted a direct link with the New Zealand Tourism Strategy; only three (out of 26 TLAs that had tourism plans) directly aligning with the national strategy. Many TLAs ( $40 \%$ of 40 respondents) did not consider there to be any tourism issues of concern in their districts (but local councils may not have the skills or resources to recognise and monitor the impacts of tourism (Page and Hall, 1999)). The study's authors conclude that there is a still a major gap between strategy and implementation, and that while sustainability has become a central tenet across a range of tourism policy in New Zealand, much of this remains a philosophical stance.

\section{Sustainable tourism in the Catlins}

The Catlins is a developing destination in the far south of the country. The destination faces a number of sustainability challenges. Most importantly, the Catlins supports significant populations of marine wildlife, being one of the few places in New Zealand where tourists can 
readily observe seals, sea lions, dolphins and penguins at close quarters. Tourist impacts on some species have been documented and pressure continues to mount, with some wildlife habitats receiving up to 100,00o largely unmanaged visitors per annum. Developing a tourism industry largely centred upon vulnerable habitats and wildlife populations will be a critical measure of the success of the sustainability of tourism in the Catlins (Lovelock and Boyd, 2006). A further challenge, however, lies in protecting local communities in the area from undesirable development. The total population of the region is only about 5,000 and, to many residents, tourism is seen as a threat to the maintenance of their traditional lifestyle, while placing more pressure on an already stretched infrastructure (Lovelock and Boyd, 2006).

In 2004, as a part of a consultancy team, the author was involved in the development of the Catlins Tourism Strategy. The strategy was ostensibly a community-driven, bottom-up policy, initiated in the face of increasing visitor numbers to: 'manage tourism growth and maximise opportunities for the future while maintaining and protecting the integrity of the community, wildlife and the environment' (Lovelock et al.). Following an extensive programme of community consultation, a number of strategic objectives were developed under the umbrella goal of taking tourism forward into the 21st century in a sustainable manner. Objectives included providing for the protection of natural and cultural resources from the negative physical impacts of tourism, and optimising the value of tourism for local residents, including social and economic benefits. Beneath these objectives, over 80 recommendations were developed. Given the critical role of RTOs in sustainable tourism governance, a key recommendation was to create a local tourism organisation with specific roles to implement sustainable tourism policies. The consultants' vision was that this proposed RTO, 'Tourism Catlins', would play a key role in 'statutory advocacy for the protection of conservation and heritage values through input to conservation planning and resource management processes' (Lovelock, et al., 2004, p.115).

But in reality, this was not a vision shared by key personnel from the agencies funding the strategy development. Two agencies were involved, the Clutha District Council (a TLA) and Venture Southland, an economic development agency funded jointly by the Invercargill City Council, Southland District Council and Gore District Council. strategy (Albrecht, 2009; Lovelock and Boyd, 2006).

The above issues, together with the fact that the strategy was prepared by tourism consultants (not regional planners) and did not integrate key actors from within the districts' RMA policy domains, collectively undermine the legitimacy of the Catlins Tourism Strategy as a resource management document.

Notwithstanding the above challenges,

\section{Somewhat disturbingly, Queenstown as arguably our most important tourism destination and the one facing the most pressing tourism-related issues, has no tourism strategy... Rather, planning for sustainable tourism is undertaken by proxy through a number of statutory and non-statutory processes.}

The manager from Venture Southland charged with overseeing the strategy development played an instrumental role in emasculating a number of policies relating to sustainable tourism in $\mathrm{draft}$ versions of the plan. In retort to the consulting team's defence that most of these policies had arisen through community consultation, he replied that this was not a community-driven or -owned strategy; the message was clear that this was a council-owned strategy and that any policies unacceptable to the council would be dropped.

Consequently, the proactive RTO Tourism Catlins that could have played a key role in sustainable tourism implementation would end up being but a shadow of the original vision for that organisation. Poor resourcing, uncertainties over continuity of staffing and support, the strains of volunteerism, personality conflicts and intra-regional conflict have ultimately hamstrung the organisation that did emerge through the the tourism organisation there has made incremental gains in terms of addressing sustainability problems (e.g. introducing a Catlins Care Code, developing an interpretation plan; and contributing to a freedom camping policy and by-law). However, the integration between local tourism strategy and RMA processes was never to occur. The voluntary nature of Tourism Catlins, lack of specific statutory planning skills, the fact that most members are tourism operators themselves, and the small, close-knit nature of the community present further impediments to the organisation being able to engage freely and actively in RMA planning processes relevant to tourism.

\section{Sustainable tourism in Queenstown}

Queenstown is New Zealand's fastestgrowing tourist destination. Located in a nationally significant landscape, and promoted as the 'Adventure Capital of New Zealand', Queenstown has grown from being a local to an international 
destination in a relatively short time. Now boasting 2.5 million visitor nights (in 2010), it is the only area in New Zealand whose economy is almost entirely dependent upon the tourism industry. As a consequence of many years of unfettered growth (particularly under the mayoralty of Warren Cooper, 1995-2001), Queenstown faces a number of issues that could collectively be grouped under the heading of 'growth management', including traffic congestion, urban centre design problems, urban sprawl and loss of landscape integrity, waste management,
Rather, planning for sustainable tourism is undertaken by proxy through a number of statutory and non-statutory processes. Paramount has been the district plan, although the limitations of this have been realised, immediate past mayor Clive Geddes commenting that despite the RMA's premise that it is about the wise and proper use of a resource:

it is, in the end, enabling legislation that allows any applicant to apply for any activity, which is not prohibited on any piece of land regardless of what

\section{...there still appears to be a substantial implementation gap between the sustainable rhetoric within national and local tourism strategies and reality at the local level.}

and an escalating cost of living for locals.

Somewhat disturbingly, Queenstown, as arguably our most important tourism destination and the one facing the most pressing tourism-related issues, has no tourism strategy. In a recent conversation with a manager at Destination Queenstown, the RTO, I was told that Destination Queenstown does not engage in tourism management, only marketing. This focus comes about partly through its funding arrangements, as an organisation originating from and funded by tourism businesses, rather than being TLA-funded and-managed, as is the prevalent model for RTOs in New Zealand. Destination Queenstown was formed in 1985 to 'collectively promote Queenstown to the world' (Destination Queenstown, 2011). It is funded by commercial ratepayers via an annual levy collected by the TLA, the Queenstown Lakes District Council (QLDC). With 11 staff members, it is one of the biggest RTOs in the country, and arguably would have the capacity to engage in planning for sustainable tourism, but this appears to be outside the organisation's mandate. the district plan says. As long as it is based on that fundamental premise it will continue to be a muddled way of trying to achieve sustainable growth. (Geddes, in Wilson, 2010, p.10)

Due to the importance of tourism in Queenstown, practically any public policy is a tourism-related policy. A second approach to addressing tourism issues has been through Tomorrow's Queenstown, the community plan developed in 2002 (QLDC, 2002), which identifies a main community outcome of sustainable growth management. This is further articulated in A Growth Management Strategy for the Queenstown Lakes District (QLDC, 2007), another non-statutory document that provides an overview of QLDC's growth management policy. This document is described as an 'expression of the legislative intent' of the council, and the council's intention is to translate the actions identified in the strategy into appropriate statutory documents. The strategy will be reviewed every six years, timed to provide input into the long-term council community plan process (required under the Local Government Act 2002). It is the council's aim that such growth management plans seek to 'alter the fundamental dynamics of land use development, rather than try to catch development once areas start to develop (as tends to be the case under the Resource Management Act)' (QLDC, 2007, p.xx).

However, the non-statutory nature of these plans poses challenges to their legitimacy. The Queenstown Lakes District Council acknowledges that at the moment the Tomorrow's Queenstown community plan is not given a lot of weight in the statutory decisionmaking process for new development proposals (QLDC, 2009). Wilson in her study of sustainability planning options for Queenstown also indicates that, although Queenstown is in the process of implementing a community sustainability plan, there are problems around legitimacy and operationalisation 'due to the ad hoc nature of its implementation and the statutory limitations imposed on the Queenstown Lakes District Council' (Wilson, 2010, p.2).

\section{Conclusion}

The rhetoric of sustainability is pervasive, the concept touted internationally through Tourism New Zealand's \$70 million annual promotion of its ' $100 \%$ Pure' brand, and nationally through two national tourism strategies. With an overarching sustainable development planning framework (the RMA), one would think New Zealand to be in a strong position to operationalise sustainable tourism. Yet there still appears to be a substantial implementation gap between the sustainability rhetoric within national and local tourism strategies and reality at the local level. While TLAs have been active in developing new tourism plans and strategies, the links with national-level strategy are weak. Furthermore, most of these plans have a focus on marketing and economic outcomes. This has been linked to the economic development imperative of TLAs and the short-term horizon of political governance (Dodds and Butler, 2010; Yasarata et al., 2010).

This article has pointed to lack of policy legitimacy as a key obstacle to 
operationalising the sustainable tourism ideals contained within these plans. While such plans may have community and industry stakeholder buy-in and thus input legitimacy within the immediate tourism policy domain, because of the way they are developed, by tourism specialists (often marketers within RTOs) or by tourism consultants, they have limited legitimacy outside the tourism domain. The lack of a legal status for tourism planning, and lack of legislative connection between tourism and other statutory policy processes, is also seen to have an impact on the legitimacy of tourism policy.

Links to the RMA have been identified as being critical to developing tourism sustainably in New Zealand. Queenstown, despite its lack of a dedicated tourism strategy, has historically relied upon RMA processes and its district plan to deal with tourism's impacts. But this has clearly been inadequate. More recently, the TLA there has turned to non-statutory processes to provide more strategic guidance to tourism planning. Ironically, the strategic approach taken by the Queenstown Lakes District Council, while meeting one of the central tenets of sustainable tourism planning (Ruhanen, 2010) has undermined the legitimacy of the policy output. Strategic plans cannot always be linked to statutory processes, and it is this weakness that may contribute to implementation failure.
In contrast, the Catlins has a highlydetailed tourism strategy with a strong sustainability flavour. Yet the process of developing the strategy was flawed, and its policy legitimacy is challenged. RTOs are critical institutions for sustainable policy implementation, and in the Catlins, an emasculated RTO reliant upon unskilled and overworked volunteers can play little or no role in linking the laudable policies of the tourism strategy with RMA processes. Small TLAs in remote areas, with limited funding to support management rather than marketing functions of RTOs, coupled with the political realities of small communities, and tourism boards that are dominated by development-oriented tourism operators, pose further challenges.

In both the Catlins and in Queenstown, achievement of sustainability initiatives has also been hampered at times by a lack of collaboration and cooperation (Lovelock and Boyd, 2006; Wilson, 2010). RTOs can play an important role here; indeed the New Zealand Tourism Strategy 2010 recognises this in its brave 'New RTOs' that would lead the way in tourism planning. However, in Queenstown, for historical, funding and functional reasons Destination Queenstown has limited its coordinating role to marketing activities. Arguably, a more holistic approach on the part of Destination Queenstown could lead to more sustainable outcomes - or at least open up greater dialogue between the tourism sector and local planners and thus better links to statutory planning processes.

What does the future hold? Local Government New Zealand envisages an approach in which strategic planning for tourism is combined with a mix of some statutory RMA policies, together with some non-RMA policies and methods (Local Government New Zealand, 2004). But to gain more traction on this would need greater institutional guidance. Sadly, the recent (2010) disestablishment of the Ministry of Tourism and creation of a much-downsized Tourism Strategy Group subsumed within the Ministry of Economic Development has affected policy capacity at the national level. There is a risk of underestimating the state's continuing significance in tourism governance (Bramwell, 2011). But the very fact of that continuance is challenged by neo-liberal reforms such as that noted above, which affect the capacity of governments to govern for sustainable tourism (Beaumont and Dredge, 2009; Dinica, 2008; Lovelock and Boyd, 2006). Such actions detract from the legitimacy of our national tourism strategy and send the wrong messages to regional planners regarding the implementation of sustainable tourism.

\section{References}

Albrecht, J.N. (2009) 'The Implementation of Tourism Strategies: a critical analysis of two New Zealand case studies', PhD thesis, University of Otago

Beaumont, N. and D. Dredge (2009) 'Local tourism governance: a comparison of three network approaches', Journal of Sustainable Tourism, 18 (1), pp.7-28

Bramwell, B. (2011) 'Governance, the state and sustainable tourism: a political economy approach', Journal of Sustainable Tourism, 19 (4-5), pp.459-77

Bramwell, B. and B. Lane (2000) Tourism Collaboration and Partnerships: politics, practice and sustainability, Clevedon: Channel View Publications

Connell, J., S.J. Page and T. Bentley (2009) 'Towards sustainable tourism planning in New Zealand: monitoring local government planning under the Resource Management Act', Tourism Management, 30, pp.867-77

Destination Queenstown (2011) About Destination Queenstown, http:// www.queenstown-nz.co.nz/information/aboutDQ/, accessed 28 June 2011
Dinica, V. (2008) 'Challenges for sustainable tourism governance in The Netherlands', International Journal of Tourism Policy, 1 (4), pp.33552

Dinica, V. (2009) 'Governance for sustainable tourism: a comparison of international and Dutch visions', Journal of Sustainable Tourism, 17 (5), pp.583-603

Dodds, R. and R. Butler (2010) 'Barriers to implementing sustainable tourism policy in mass tourism destinations', Tourismos: An International Multidisciplinary Journal of Tourism, 5 (1), pp.35-53

Dredge, D., E. Ford, and M. Whitford (2011) 'Managing local tourism: building sustainable tourism management practices across local government divides', Tourism and Hospitality Research, 11 (2), pp.101-16

Dredge, D. and J. Jenkins (2007) Tourism Policy and Planning, Milton, Australia: John Wiley and Sons

Hall, C.M. (2011) 'Policy learning and policy failure in sustainable tourism governance: from first- and second-order to third-order change?', Journal of Sustainable Tourism, 19 (4-5), pp.649-71 
Local Government New Zealand (2003) Postcards from Home: the local government tourism strategy, Wellington: Local Government New Zealand

Local Government New Zealand (2004) Tourism and the Resource Management Act: a good practice guide, prepared by Becca Carter Hollings \& Ferner Ltd and Tourism Resource Consultants Ltd, Wellington: Local Government New Zealand

Lovelock, B. and S. Boyd (2006) 'Impediments to a cross-border collaborative model of destination management in the Catlins, New Zealand', Tourism Geographies, 8 (2), pp.143-61

Lovelock, B.A., S. Boyd and W. Low (2004) Catlins Tourism Strategy 2004, Invercargill: Catlins Tourism Strategy Working Party, Venture Southland and Clutha Economic Development Board

McLennan, C. and L. Ruhanen (2008) Analysis of Territory, Regional and Local Tourism Strategies and Plans: identification of strategic issues, Gold Coast, Queensland: Co-operative Research Centre for Sustainable Tourism

Ministry of Tourism (2007) New Zealand Tourism Strategy 2015, Wellington: Ministry of Tourism

Page, S.J. and C.M. Hall (1999) 'New Zealand country report', International Tourism Reports, 4, pp.47-76

Parliamentary Commissioner for the Environment (1997) Management of the Environmental Effects Associated with the Tourism Sector, Wellington: Office of the Parliamentary Commissioner for the Environment

Pike, S. (2004) Destination Marketing Organisations, Oxford: Elsevier

Queenstown Lakes District Council (2002) Tomorrow's Queenstown: vision, issues and directions, Queenstown: Queenstown Lakes District Council

Queenstown Lakes District Council (2007) A Growth Management Strategy for the Queenstown Lakes District, Queenstown: Queenstown Lakes District Council

Queenstown Lakes District Council (2009) 'Queenstown Lakes District Council Strategy Committee for meeting of 13 October 2009: report for agenda item 2', unpublished report

Rhodes, R. (1996) 'The new governance: governing without government', Political Studies, 44 (4), pp.652-67
Rothstein B. (2008) Political Legitimacy and the Welfare State: five basic mode/s, working paper 2008: 9, Gothenburg: Quality of Government Institute, Department of Political Science, University of Gothenburg

Ruhanen, L. (2008) 'Progressing the sustainability debate: a knowledge management approach to sustainable tourism planning', Current Issues in Tourism, 11 (5), pp.429-55

Ruhanen, L. (2010) 'Where's the strategy in tourism strategic planning? Implications for sustainable tourism destination planning', Journal of Travel and Tourism Research, Spring/Fall, pp.58-76

Ruhanen, L., S. Reid and M. Davidson (2011) 'Compromising sustainable tourism development: the absence of legislation in tourism destination planning', in M.J. Gross (ed.), CAUTHE 2011 National Conference: tourism: creating a brilliant blend, Adelaide: University of South Australia School of Management, http://search.informit.com.au/docu mentSummary; $\mathrm{dn}=915084832609819 ;$ res=IELHSS, accessed 28 June 2011

Smoke, R. (1994) 'On the importance of policy legitimacy', Political Psychology, 15 (1), pp.97-110

Tourism Strategy Group (2001) New Zealand Tourism Strategy 2010, Wellington: Ministry of Tourism/Tourism Strategy Group

United Nations Environment Programme (2003) Tourism and Local Agenda 21: the role of local authorities in sustainable tourism, Paris: United Nations Environment Programme and International Council for Local Environmental Initiatives

United Nations World Tourism Organization (2004) Making Tourism More Sustainable: a guide for policy makers, Madrid: United Nations World Tourism Organization

Wearing, S. and J. Neil (2009) Ecotourism: impacts, potentials and possibilities, Oxford: Butterworth-Heinemann

Wilson, C. (2010) 'Tourism resorts and sustainability: a comparative study of the public policy techniques of Whistler, British Columbia and Queenstown, New Zealand', unpublished Ministry of Tourism research scholarship report

Yasarata, M., L. Altinay, P. Burns and F. Okumus (2010) 'Politics and sustainable tourism development: can they co-exist? Voices from North Cyprus', Tourism Management, 31, pp.345-56

Zahra, A.L. (2011) 'Rethinking regional tourism governance: the principle of subsidiarity', Journal of Sustainable Tourism, 19 (4-5), pp.535-52 